\title{
Analisis Permintaan Buah Pisang Di Kota Denpasar, Bali
}

\author{
P. K. SUPARYANA, W. RAMANTHA ${ }^{\text {) }}$, W. BUDIASA ${ }^{2)}$ \\ Program Studi Magister Agribisnis, Program Pascasarjana, Universitas Udayana, \\ E-mail: panko.suparyana@gmail.com \\ ${ }^{1)}$ Fakultas Ekonomi dan Bisnis, Universitas Udayana \\ ${ }^{2)}$ Program Studi Agribisnis, Fakultas Pertanian, Universitas Udayana
}

\section{ABSTRACT \\ Demand Analysis For Bananas In Denpasar City}

This study aims at finding out factors influencing demand for bananas and calculating price, income and cross elasticies of demand for bananas in Denpasar. The study focuses on household consumers in Denpasar City including 100 respondents. Data were analyzed using multiple linear regression considering economic, econometrics and statistics criteria.

Based on the linear regression analysis, the demand model for bananas in Denpasar is $\ln \mathrm{Y}=-43,156-0,139 \ln \mathrm{X}_{1}-0,600 \ln \mathrm{X}_{2}-0,378 \ln \mathrm{X}_{3}+5,896 \ln \mathrm{X}_{4}+0,776$ $\ln \mathrm{X}_{5}+3,365 \quad \ln \mathrm{X}_{6}+0,418 \quad \ln \mathrm{X}_{7}+0,548 \quad \ln \mathrm{D}$. All independent variables are simultaneously significant affecting demand for bananas in Denpasar. Partially, prices of zalacca, rambutan, total income, number of household members, and purpose of purchasing significantly affecting demand for bananas. Meanwhile, price of bananas, price of oranges, and price of mangoes do not have significant effect on demand for bananas. Price elasticity of demand for bananas shows an inelastic figure $(e<1)$, implying that demand for bananas is not responsive to the price changes. A positive sign in the value of the income elasticity indicates that banana is a normal good. Sign of the cross-price elasticity of oranges and mango prices was negative, referring that these fruits are complementary to bananas. On the other hand, cross-price elasticities of zalacca and rambutan are positive, meaning that zalacca and rambutan are substitute commodities to bananas.

Keywords: demand for bananas, regression, elasticity, household, Denpasar

\section{Pendahuluan}

Buah-buahan merupakan salah satu produk hortikultura yang mempunyai nilai ekonomis yang tinggi dan potensi pasar yang cukup baik. Permintaan pasar terhadap buah-buahan semakin meningkat, baik pasar dalam negeri maupun pasar internasional. Salah satu komoditi pertanian pada sub sektor hortikultura sebagai sumber karbohidrat yang sarat gizi seperti buah pisang diperkirakan akan mengalami kenaikan permintaan sehingga mempunyai potensi yang sangat besar untuk dikembangkan. Manfaat tanaman 
pisang tidak hanya dapat digunakan buahnya, akan tetapi dari bongkol, batang, sampai daunnya sangat diperlukan dalam menunjang kehidupan sehari-hari. Pisang merupakan komoditas unggulan yang memiliki kontribusi besar terhadap produksi buah-buahan nasional. Selain memiliki potensi yang besar dalam menunjang peningkatan pendapatan masyarakat petani, pisang juga merupakan bahan baku industri olahan (untuk chip, keripik, puree, tepung) dan komoditas yang potensial untuk meningkatkan ekspor buah (Departemen Pertanian, 2014).

Menurut hasil perhitungan statistik hortikultura tahun 2014 oleh Departemen Pertanian, produksi tanaman pisang memberikan sumbangan sekitar 42,08 persen terhadap total produksi buah di Jawa dan daerah Luar Jawa sekitar 27,19 persen terhadap total produksi buah di Luar Jawa. Lima buah-buahan yang banyak dikonsumsi oleh masyarakat Bali yaitu: pisang, jeruk, salak, mangga, dan rambutan. Dari studi pendahuluan yang dilakukan, kebutuhan buah di Bali sangat tinggi dan melebihi kemampuan produksi petani Bali. Pedagang di pasar Batukandik pada hari-hari biasa di luar hari Raya mendatangkan pisang tiga truk dalam satu minggu, dengan jumlah 600 tandan (6.000 sisir) dalam satu truk. Beberapa tahun ini banyak pisang didatangkan dari luar Bali untuk memenuhi kebutuhan pisang yang sangat tinggi di Bali, terutama saat hari raya umat Hindu Bali. Pisang tersebut didatangkan dari Lumajang dan Banyuwangi.

Harga produk pangan di pasar terbentuk dari keseimbangan antara penawaran dan permintaan. Peningkatan maupun penurunan harga dapat menjadi sinyal perubahan ketersediaan produk, perubahan tingkat konsumsi masyarakat, ataupun keduanya secara simultan. Harga yang terus naik tajam dapat disebabkan oleh langkanya produk di pasar, naiknya permintaan masyarakat, atau kombinasi keduanya. Harga yang terus menurun dapat terjadi karena melimpahnya pasokan produk. Salah satu alasan pentingnya informasi harga dikumpulkan adalah tingkat harga dapat dengan cepat memberikan sinyal perubahan penawaran dan permintaan (Firdaus, 2006).

Provinsi Bali mempunyai luas wilayah 563.666 ha dengan jumlah penduduk 3.686.665 jiwa (BPS, 2015) merupakan pangsa pasar yang potensial bagi produk hortikultura. Permintaan terhadap beberapa produk hortikultura secara periodik pada bulan-bulan tertentu setiap tahunnya sering terjadi lonjakan permintaan terutama untuk memenuhi permintaan hari raya umat Hindu (Galungan, Kuningan, piodalan, dan hari raya lainnya). Kota Denpasar merupakan kota administratif dan pusat kegiatan ekonomi di Bali, sehingga penduduknya sangat padat yang merupakan pelanggan potensial untuk mengkonsumsi buah pisang. Sampai saat ini belum terdapat catatan pasti mengenai jumlah permintaan buah pisang di Kota Denpasar. Oleh karena itu perlu dilakukan suatu penelitian tentang analisis permintaan buah pisang oleh konsumen rumah tangga. Berdasarkan pemikiran tersebut, maka penelitian mengenai "Analisis Permintaan Buah Pisang di Kota Denpasar, Bali” penting untuk dilakukan.

Berdasarkan latar belakang masalah tersebut di atas, maka pokok permasalahan dalam penelitian ini adalah: 
1. Bagaimana pengaruh variabel harga buah pisang, harga buah selain pisang, pendapatan, jumlah anggota keluarga, dan tujuan pembelian terhadap permintaan buah pisang secara simultan.

2. Bagaimana pengaruh variabel harga buah pisang, harga buah selain pisang, pendapatan, jumlah anggota keluarga, dan tujuan pembelian terhadap permintaan buah pisang secara parsial.

3. Bagaimana elastisitas permintaan buah pisang di Kota Denpasar

Adapun tujuan penelitian ini adalah sebagai berikut:

1. Untuk mengetahui pengaruh variabel harga buah pisang, harga buah selain pisang, pendapatan, jumlah anggota keluarga dan tujuan pembelian terhadap permintaan buah pisang secara simultan.

2. Untuk mengetahui pengaruh variabel harga buah pisang, harga buah selain pisang, pendapatan, jumlah anggota keluarga dan tujuan pembelian terhadap permintaan buah pisang secara parsial.

3. Untuk mengetahui elastisitas permintaan buah pisang di Kota Denpasar

\section{Kajian Pustaka}

\section{Fungsi Permintaan}

Jumlah permintaan dari suatu barang adalah jumlah barang yang rela dan mampu dibayar oleh pembeli. Banyak hal yang menentukan jumlah permintaan barang, salah satu penentunya adalah harga dari barang itu. Hubungan antara harga dan jumlah permintaan ini berlaku untuk kebanyakan jenis barang dalam perekonomian, dan faktanya hal ini begitu umum sehingga para ekonom menyebutnya sebagai hukum permintaan: jika semua hal dibiarkan sama, ketika harga suatu barang meningkat, maka jumlah permintaannya akan menurun, dan ketika harganya turun, maka jumlah permintaannya akan naik (Mankiw, 2011).

\section{Konsep Elastisitas}

Elastisitas adalah ukuran kuantitatif yang menunjukkan seberapa besar pengaruh perubahan harga atau faktor-faktor lainnya terhadap perubahan permintaan dan penawaran dari suatu komoditas (Lipsey RG et al,. 1995). Ada tiga macam elastisitas yang berhubungan dengan permintaan yaitu elastisitas harga, elastisitas silang dan elastisitas pendapatan (Boediono 2000).

\section{Elastisitas Permintaan}

Elastisitas harga atau elastisitas permintaan adalah persentse perubahan jumlah yang diminta yang disebabkan oleh perubahan harga barang tersebut sebesar satu persen (Lipsey RG et al. 1995). Besarnya elastisitas harga bervariasi antara nol sampai tak hingga, dengan kriteria nilai elastisitas sebagai berikut :

$\mathrm{e}=0$, artinya jika jumlah yang diminta tidak tanggap sama sekali terhadap persentase perubahan harga (inelastis sempurna) 
$\mathrm{e}=\infty$, artinya jika terdapat peningkatan permintaan suatu barang walaupun tidak terjadi peningkatan harga barang (elastis sempurna)

e $<1$, artinya jika persentase perubahan kuantitas lebih kecil dari perubahan harga, permintaannya bersifat inelastis

$\mathrm{e}=1$, artinya jika persentase perubahan kuantitas dan harga sama dengan satu (elastis uniter)

e $>1$, artinya jika persentase perubahan kuantitas melampaui persentase perubahan harga, permintaannya bersifat elastis

\section{Elastisitas pendapatan}

Elastisitas pendapatan adalah derajat reaksi permintaan terhadap perubahan pendapatan. Untuk kebanyakan jenis barang, kenaikan pendapatan berakibat kenaikan permintaan dan elastisitas terhadap permintaan akan positif. Barang-barang demikian disebut barang normal. Barang-barang yang konsumsinya menurun sebagai tanggapan terhadap kenaikan pendapatan memiliki elastisitas pendapatan yang negatif dan disebut barang inferior (Lipsey RG et al. 1995).

\section{Elastisitas silang}

Elastisitas silang adalah besarnya reaksi permintaan terhadap perubahan hargaharga dari komoditas lain. Komoditas-komoditas yang tergolong komplementer mempunyai elastisitas silang yang negatif, sedangkan komoditas-komoditas yang tergolong substitusi mempunyai elastisitas silang yang positif (Lipsey RG et al. 1995).

\section{Tingkat Substitusi Marginal (Marjinal Substitution Rate)}

Tingkat substitusi marginal merupakan besarnya pengurangan jumlah konsumsi barang yang satu untuk menaikkan konsumsi satu satuan barang lainnya, dengan tetap mempertahankan tingkat kepuasannya (Pappas and Hirschey, 1995).

\section{Kerangka Konsep Dan Hipotesis}

Buah pisang merupakan komoditas pertanian yang dikonsumsi dan diminati oleh masyarakat, diantaranya adalah masyarakat yang bermukim di Kota Denpasar. Sampai saat ini belum terdapat catatan pasti mengenai jumlah permintaan buah pisang di Kota Denpasar, maka perlu dilakukan suatu penelitian tentang analisis permintaan buah pisang oleh konsumen rumah tangga. Penelitian ini bertujuan untuk mengetahui faktorfaktor yang mempengaruhi terhadap permintaan buah pisang, faktor-faktor tersebut adalah harga buah pisang itu sendiri, harga buah selain buah pisang (seperti jeruk, mangga, salak, rambutan), jumlah pendapatan keluarga, jumlah anggota keluarga dan tujuan pembelian. Analisis yang digunakan antara lain analisis regresi linier berganda dan analisis respon elastisitas. Hasil analisis memberikan informasi tentang faktorfaktor yang mempengaruhi jumlah permintaan terhadap buah pisang oleh konsumen rumah tangga. Berdasarkan permasalahan dan tujuan penelitian yang ada, maka dapat dirumuskan hipotesis $(\mathrm{H})$ sebagai berikut: 
1. Permintaan buah pisang dipengaruhi secara serempak oleh harga buah pisang, harga buah selain buah pisang, pendapatan, jumlah anggota keluarga dan tujuan pembelian.

2. Permintaan buah pisang dipengaruhi secara parsial oleh harga buah pisang, harga buah selain buah pisang, pendapatan, jumlah anggota keluarga, dan tujuan pembelian.

\section{Metode Penelitian}

Penelitian ini dilakukan di Kota Denpasar. Pemilihan lokasi penelitian ini berdasarkan pertimbangan:

1. Kota denpasar merupakan pusat aktivitas di Provinsi Bali.

2. Banyaknya terdapat pasar buah tradisional maupun modern yang mencerminkan tingginya permintaan buah di Kota Denpasar.

3. Titik pengambilan sampel dilakukan di Desa Pemogan, Kelurahan Sesetan, Desa Kesiman Kertalangu, Desa Sumerta Klod, Desa Pemecutan Klod, Desa Padang Sambian, Desa Pemecutan Kaja, Desa Ubung Kaja. Pengambilan titik penelitian dengan pertimbangan desa tersebut mewakili keempat Kecamatan yang ada di Denpasar dengan daerah yang relatif padat penduduknya.

Populasi dalam penelitian ini adalah keluarga yang tinggal di Kota Denpasar. Pengambilan jumlah sampel dilakukan dengan menggunakan formulasi rumus Slovin (Kastro dan Mantra, 1995). Penggunaan rumus tersebut disesuaikan dengan jumlah keluarga yang ada di kota Denpasar sebanyak 264.960 keluarga (BPS, 2015). Dari perhitungan dengan menggunakan formulasi tersebut, maka jumlah sampel yang diambil adalah 100 keluarga. Pemilihan rumah tangga sebagai responden disetiap Kecamatan berdasarkan metode accidental sampling, yaitu responden yang digunakan merupakan seorang ibu rumah tangga atau seorang ayah dengan keputusan sendiri dalam membelanjakan pendapatannya dan kebetulan bertemu dengan peneliti

\section{Uji asumsi klasik}

Uji asumsi klasik dilakukan sebelum penggunaan analisis regresi linier berganda untuk mnenghindari penyimpangan supaya tidak timbul masalah dalam penggunaan analisis regresi linier berganda (Ghozali, 2002). Adapun jenis uji asumsi klasik yang digunakan dalam penelitian adalah:

1. Uji normalitas

Uji normalitas bertujuan untuk menguji apakah dalam analisis model regresi, variabel terikat dan variabel bebas keduanya mempunyai distribusi normal atau tidak.

2. Uji heteroskedastistas

Uji ini bertujuan untuk menguji apakah dalam model regresi terjadi ketidaksamaan varians dari residual satu pengamatan ke pengamatan lainnya.

\section{Uji multikolinieritas}


Uji multikolinieritas bertujuan untuk menguji apakah didalam model regresi ditemukan adanya korelasi antar variabel bebas (independent).

\section{Uji Statistik}

1. Uji Koefisien Regresi secara Serentak (Uji F)

Uji F digunakan untuk menguji tingkat signifikansi parameter secara bersama- sama dari variabel yang diukur terhadap variabel terikat, apakah dapat diterima secara statistikk dengan membandingkan $\mathrm{F}$ hitung dan $\mathrm{F}$ tabel.

2. Uji Koefisien Regresi secara Parsial (Uji t)

Pengujian ini dilakukan untuk mengetahui apakah masing- masing variabel bebas secara individu berpengaruh terhadap variabel terikat. Uji t merupakan metode pengujian hipotesis secara parsial terhadap koefisien regresi yaitu dengan membandingkan nilai statistik masing- masing koefisien regresi dengan nilai t tabel sesuai dengan tingkat signifikansi yang digunakan.

\section{Analisis Respon (Elastisitas Permintaan)}

Model persamaan penduga permintaan yang telah ditransformasi ke dalam bentuk logaritma natural $Y=a X^{b i}$, bisa langsung didapatkan nilai elastisitasnya yaitu sebesar bi (Baye dan Prince, 2016). Tujuan penelitian ini adalah ingin menentukan elastisitas permintaannya, maka digunakan model persamaaan penduga permintaan buah pisang, yaitu sebagai berikut:

$\mathrm{Y}=f\left(\mathrm{X}_{1}, \mathrm{X}_{2}, \mathrm{X}_{3}, \mathrm{X}_{4}, \mathrm{X}_{5}, \mathrm{X}_{6}, \mathrm{X}_{7}, \mathrm{D}\right)$

atau

$\mathrm{Y}=\beta_{0} \cdot X_{1}^{\beta 1} \cdot X_{2}^{\beta 2} \cdot X_{3}^{\beta 3} \cdot X_{4}^{\beta 4} \cdot X_{5}^{\beta 5} \cdot X_{6}^{\beta 6} \cdot X_{7}^{\beta 7} \cdot D^{\beta 8} \cdot e^{\mu i}$

Dengan mentransformasikan model tersebut dalam bentuk logaritma natural, sehingga menjadi lebih sederhana sebagai berikut :

$$
\begin{gathered}
\ln Y=\beta_{0}+\beta_{1} \ln X_{1}+\beta_{2} \ln X_{2}+\beta_{3} \ln X_{3}+\beta_{4} \ln X_{4}+\beta_{5} \ln X_{5}+\beta_{6} \ln X_{6}+\beta_{7} \ln X_{7} \\
+\beta_{8} \ln D+\mu i
\end{gathered}
$$

Keterangan :

$\mathrm{Y}=$ jumlah permintaan buah pisang

$\beta_{0}=$ konstanta

$\beta_{1}=$ koefisien regresi untuk harga rata-rata buah pisang

$\beta_{2}=$ koefisien regresi untuk harga rata-rata buah jeruk

$\beta_{3}=$ koefisien regresi untuk harga rata-rata buah mangga

$\beta_{4}=$ koefisien regresi untuk harga rata-rata buah salak

$\beta_{5}=$ koefisien regresi untuk harga rata-rata buah rambutan

$\beta_{6}=$ koefisien regresi untuk pendapatan per bulan

$\beta_{7}=$ koefisen regresi untuk jumlah anggota keluarga

$X_{1}=$ harga rata-rata buah pisang

$X_{2}=$ harga rata-rata buah jeruk

$X_{3}=$ harga rata-rata buah mangga

$X_{4}=$ harga rata-rata buah salak

$X_{5}=$ harga rata-rata buah rambutan 
$X_{6}=$ pendapatan per bulan

$X_{7}=$ jumlah anggota keluarga

$D=$ Dummy Variabel yaitu tujuan pembelian buah pisang; $\mathrm{D}=1$ jika tujuan pembelian untuk konsumsi langsung; $\mathrm{D}=0$ jika tujuan pembelian untuk upacara agama

maka dapat diketahui elastisitas harga, elastisitas pendapatan, serta elastisitas silangnya adalah sebagai berikut :

Elastisitas harga $\left(\varepsilon_{\mathrm{p}}\right)=\beta_{1}$

Elastisitas pendapatan $\left(\varepsilon_{\mathrm{I}}\right) \quad=\beta_{6}$

Elastisitas harga $\left(\varepsilon_{\mathrm{S}}\right)=\beta_{2}, \beta_{3}, \beta_{4}, \beta_{5}$

\section{Hasil Penelitian dan Pembahasan}

\section{Model Persamaan Permintaan Buah Pisang}

Hubungan variabel dependen $(Y)$ dan variabel independen $(X i)$ dengan mentransformasikan dalam bentuk logaritma natural sebagai berikut (Tabel 1):

$$
\begin{gathered}
\ln Y=\beta_{0}+\beta_{1} \ln X_{1}+\beta_{2} \ln X_{2}+\beta_{3} \ln X_{3}+\beta_{4} \ln X_{4}+\beta_{5} \ln X_{5}+\beta_{6} \ln X_{6}+\beta_{7} \ln X_{7} \\
+\beta_{8} \ln D+\mu i \\
\ln Y=-43,156-0,139 \ln X_{1}-0,600 \ln X_{2}-0,378 \ln X_{3}+5,896 \ln X_{4} \\
+0,776 \ln X_{5}+3,365 \ln X_{6}+0,418 \ln X_{7}+0,548 \ln D+\mu i
\end{gathered}
$$

\begin{tabular}{|c|c|c|c|c|c|c|c|c|}
\hline \multirow[b]{2}{*}{ Model } & & \multicolumn{2}{|c|}{$\begin{array}{l}\text { Unstandardized } \\
\text { Coefficients }\end{array}$} & \multirow{2}{*}{$\begin{array}{l}\text { Standardized } \\
\text { Coeflicients } \\
\text { Beta }\end{array}$} & \multirow[b]{2}{*}{$t$} & \multirow[b]{2}{*}{ Sig. } & \multicolumn{2}{|c|}{ Collineatity Statsisto } \\
\hline & & B & Std. Enor & & & & Tolerance & $y \neq$ \\
\hline \multirow[t]{9}{*}{1} & [Constant] & $-43,166$ & 2.879 & & $-14,889$ & .000 & & \\
\hline & xt & +139 & 247 & -018 &.,- 504 & .574 & .927 & 1,079 \\
\hline & $x_{2}$ &,+ 600 & .352 &,- 052 & $-1,703$ &, 082 & .814 & 1,228 \\
\hline & $x$ & -378 & 383 & -030 &,- 988 & 326 & 812 & 1.232 \\
\hline & $x 4$ & 5.898 & .397 & .444 & 14,867 & .000 & .846 & 1,186 \\
\hline & $x 5$ & .776 & 310 & .076 & 2,450 & .010 & 785 & 1.274 \\
\hline & $x 0$ & 3,305 & .222 & 472 & 15,128 & .000 & .770 & 1,288 \\
\hline & $x 7$ & .418 & .026 & 506 & 16,116 & .000 & 765 & 1,307 \\
\hline & $\mathrm{D}$ & 548 & .071 & 233 & 7,770 & .000 & 840 & 1,190 \\
\hline
\end{tabular}

Tabel 1

Koefisien Regresi

a. Dependent Variable: $y$

\section{Kriteria Ekonometrik}

Model dugaan yang baik harus memenuhi kriteria ekonometrika meliputi pengujian terhadap asumsi-asumsi model linear klasik yaitu asumsi normalitas, homoskedastisitas, asumsi tidak adanya multikoliniearitas. Pengujian normalitas dengan Kolmogrov-Smirnov Test diperoleh nilai KSZ sebesar 0,739 dan Asymp.sig. sebesar 0,645 lebih besar dari 0,05 maka dapat disimpulkan data berdistribusi normal, sehingga model regresi linier layak untuk memprediksi permintaan Buah Pisang (Tabel 2). Uji heterokedastisitas didapatkan titik dalam grafik plot tidak menunjukkan pola tertentu sehingga dapat dikatakan data dalam penelitian ini bebas dari heterokedastisitas (Gambar 1). Nilai - nilai VIF yang didapat dari perhitungan adalah $<10$, jadi dapat 
disimpulkan bahwa data tersebut tidak menunjukkan adanya gejala multikolinearitas (Tabel 1).

Tabel 2

Uji Normalitas

\begin{tabular}{|c|c|c|}
\hline & & $\begin{array}{l}\text { Unstandardic } \\
\text { ed Residual }\end{array}$ \\
\hline $\mathrm{N}$ & & 100 \\
\hline \multirow[t]{2}{*}{ Normal Parameters n.: } & Mean &, 0000000 \\
\hline & Std Deviation &, 28904513 \\
\hline Most Extreme & Absolute &, 074 \\
\hline \multirow[t]{2}{*}{ Ditferences } & Positive & .064 \\
\hline & Negative & -.074 \\
\hline Kolmogorov-Smirnow Z & & .739 \\
\hline Asymp Sig (2-tailed) & & 645 \\
\hline
\end{tabular}

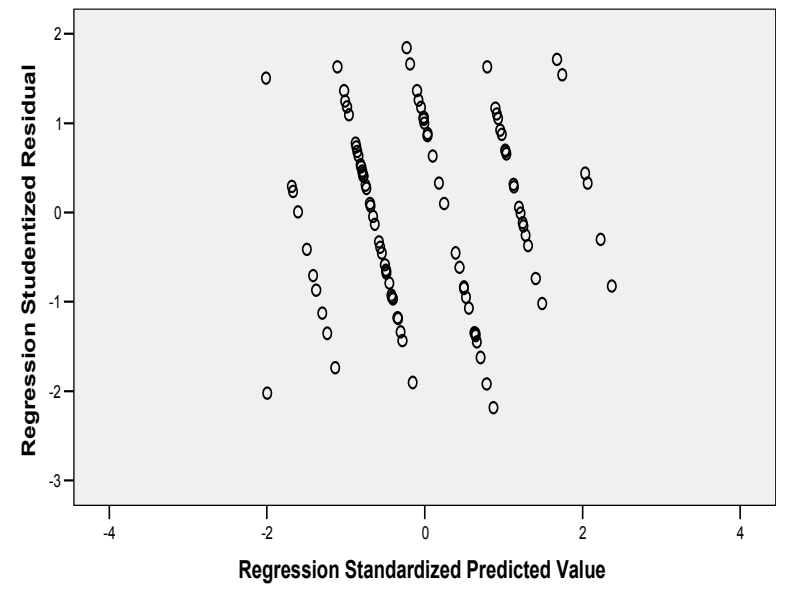

Gambar 1. Uji Heterokedastisitas

\section{Pengaruh Variabel Bebas Secara Serempak Terhadap Permintaan Buah Pisang}

Tabel 3

$$
\text { Uji F }
$$

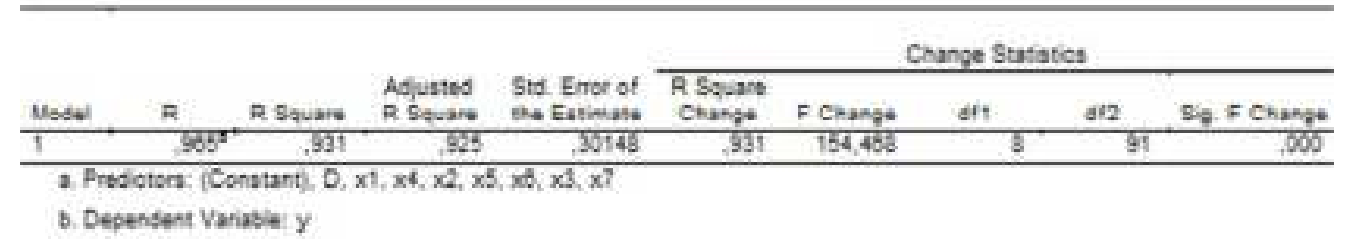

Dari hasil penelitian, harga buah pisang, harga buah jeruk, harga buah mangga, harga buah salak, harga buah rambutan, pendapatan total, jumlah anggota keluarga, dan tujuan pembelian secara serempak memberikan pengaruh signifikan terhadap permintaan buah pisang. Kenaikan atau penurunan permintaan pisang dipengaruhi oleh variabel bebas secara serempak. Hasil regresi diperoleh nilai $\mathrm{R}^{2}$ sebesar 0,931 atau 93,1\%. Ini berarti bahwa 93,1\% variasi permintaan buah pisang di Kota Denpasar dapat 
diterangkan oleh kedelapan variabel yang digunakan yaitu harga buah pisang, harga buah jeruk, harga buah mangga, harga buah salak, harga buah rambutan, pendapatan total, jumlah anggota keluarga, serta tujuan pembelian. Sisanya sebesar 0,069 atau 6,9\% diterangkan oleh faktor lain yang tidak digunakan dalam model (Tabel 3).

\section{Pengaruh Variabel Bebas Secara Parsial Terhadap Permintaan Buah Pisang}

Harga buah pisang secara parsial tidak berpengaruh signifikan terhadap permintaan buah pisang. Hal tersebut menunjukkan kenaikan dan penurunan harga buah pisang tidak mempengaruhi kenaikan dan penurunan dari permintaan buah pisang. Beberapa faktor yang mempengaruhinya yaitu: a) Pisang merupakan komoditas buah yang tidak tahan lama dan mudah rusak, sehingga konsumen rumah tangga tidak akan membeli dalam jumlah banyak untuk stok bila harga buah pisang turun. Konsumen akan membeli pisang secukupnya untuk keperluan konsumsi ataupun upacara keagamaan,b) Pisang selain sebagai pelengkap pencuci mulut setelah makan, juga banyak digunakan sebagai salah satu kebutuhan pokok sarana upacara umat Hindu. Konsumen akan tetap membeli sesuai keperluan upacara walaupun harga buah pisang mengalami kenaikan.

Harga buah jeruk dan mangga secara parsial tidak berpengaruh terhadap permintaan buah pisang. Walaupun harga jeruk dan mangga mengalami kenaikan atau penurunan tidak mempengaruhi kenaikan dan penurunan dari permintaan buah pisang. Hal ini dikarenakan karena ada variabel lain yang lebih signifikan dari harga jeruk dan mangga yang mempengaruhi permintaan pisang. Pelaksanaan upacara agama akan meningkatkan keputusan konsumen dalam membeli buah.

Harga buah salak dan rambutan secara parsial berpengaruh signifikan terhadap permintaan buah pisang. Harga buah salak dan rambutan mengalami kenaikan atau penurunan harga, buah salak dan rambutan dapat mempengaruhi kenaikan atau penurunan dari permintaan buah pisang. Konsumen mempunyai alternatif pemilihan dalam pemenuhan kebutuhannya, pemilihan salak dan rambutan karena pada saat tertentu harga salak dan rambutan lebih murah dibandingkan pisang.

Pendapatan total secara parsial berpengaruh signifikan terhadap permintaan buah pisang. Hal tersebut menunjukkan kenaikan dan penurunan pendapatan total keluarga dapat mempengaruhi kenaikan dan penurunan dari permintaan buah pisang. Pendapatan merupakan faktor yang penting dalam menentukan variasi permintaan terhadap berbagai jenis barang, karena besar kecilnya pendapatan dapat menggambarkan daya beli konsumen.

Jumlah anggota keluarga secara parsial berpengaruh signifikan terhadap permintaan buah pisang. Hal tersebut menunjukkan banyak atau sedikitnya jumlah anggota keluarga dapat mempengaruhi kenaikan dan penurunan dari permintaan buah pisang.

Tujuan pembelian secara parsial memberikan pengaruh signifikan terhadap permintaan buah pisang. Hal ini menunjukkan permintaan pisang untuk tujuan konsumsi langsung lebih besar dari tujuan upacara agama. Tujuan pembelian pisang tidak hanya sebagai pelengkap gizi saat makan atau pembasuh mulut setelah makan 
tetapi juga dibutuhkan sebagai sarana pelengkap upacara Agama Hindu. Tujuan konsumsi langsung memiliki pengaruh lebih besar dikarenakan peningkatan pendapatan yang merubah pola pikir rumah tangga dalam meningkatkan konsumsi untuk pemenuhan gizinya.

Tabel 4

Elastisitas Harga, Elastisitas Pendapatan, dan Elastisitas Silang

\begin{tabular}{|c|c|c|}
\hline Jenis Elastisitas & Nilai Elastisitas & Sifat Elastisitas \\
\hline Elastisitas Harga (buah pisang) (X1) & $-0,139$ & Inelastis $(\mathrm{e}<1)$ \\
\hline Elastisitas Pendapatan (X6) & 3,365 & Barang normal (nilai e positif) \\
\hline Elastisitas Silang: & & \\
\hline * Harga buah jeruk (X2) & $-0,600$ & $\begin{array}{l}\text { Barang komplementer } \\
\text { (nilai e negatif) }\end{array}$ \\
\hline * Harga buah mangga (X3) & $-0,378$ & $\begin{array}{l}\text { Barang komplementer } \\
\text { (nilai e negatif) }\end{array}$ \\
\hline * Harga buah salak (X4) & 5,896 & Barang substitusi (nilai e positif) \\
\hline * Harga buah rambutan (X5) & 0,776 & Barang substitusi (nilai e positif) \\
\hline
\end{tabular}

\section{Elastisitas Harga}

Elastisitas permintaan bersifat inelastis $(e<1)$ (Tabel 4). Inelastis berarti persentase perubahan jumlah buah pisang yang diminta lebih kecil dari persentase perubahan harga. Buah pisang merupakan barang kebutuhan sehari-hari dan sebagai salah satu kebutuhan pokok sarana upacara umat Hindu. Konsumen dalam mengkonsumsi pisang lebih memperhatikan manfaat yang didapatkan, sehingga harga pisang bersifat inelastis terhadap permintaannya. Menurut Gita (2013) dalam penelitiannya, di Bali ada dugaan kuat telah terjadi pergeseran untuk pengeluaran ritual dari konsumsi tersier menjadi konsumsi sekunder bahkan cenderung ke konsumsi primer.

\section{Elastisitas Pendapatan}

Elastisitas pendapatan bertanda positif menunjukkan bahwa buah pisang merupakan barang normal, dimana jika terjadi kenaikan pendapatan akan meningkatkan permintaan buah pisang dan begitu pun sebaliknya (Tabel 4). Hal ini berarti kenaikan dalam permintaan buah pisang sebagai akibat dari kenaikan pendapatan konsumen. Pada kondisi pendapatan yang terbatas, sebagian besar dari pendapatan akan dipakai untuk memenuhi kebutuhan pokok terlebih dahulu. Pendapatan penduduk yang meningkat dengan kebutuhan pokok yang sudah terpenuhi, maka konsumsi bahan pangan lainnya termasuk buah-buahan (pisang) sebagai sumber vitamin dan mineral akan meningkat. Peningkatan pendapatan ini selanjutnya berdampak pada peningkatan kemampuan untuk membeli lebih banyak barang dari biasanya.

\section{Elastisitas Silang}

Tanda elastisitas silang harga buah jeruk dan harga buah mangga adalah negatif (Tabel 4). Hal ini menunjukkan bahwa buah jeruk dan buah mangga adalah barang komplementer yang saling melengkapi terhadap buah pisang. Dalam kehidupan 
masyarakat beragama Hindu di Kota Denpasar secara tidak langsung memberikan alasan mengapa buah jeruk dan buah mangga adalah barang komplementer yang saling melengkapi bagi buah pisang. Buah pokok yang digunakan dalam banten adalah buah pisang, buah jeruk, dan buah mangga. Karena buah tersebut termasuk buah sepanjang tahun.

Tanda elastisitas silang harga buah salak dan rambutan adalah positif, berarti buah salak dan rambutan adalah komoditas barang substitusi yang dapat mengurangi jumlah pemakaian atau konsumsi terhadap buah pisang (Tabel 5). Buah salak dan buah rambutan merupakan buah musiman, yang harga saat musimnya menjadi murah dikarenakan jumlah yang melimpah. Buah salak dan rambutan digunakan sebagai barang substitusi sebagian yang dapat mengurangi sebagian jumlah pemakaian atau konsumsi terhadap buah pisang.

\section{Simpulan dan Saran}

\section{Simpulan}

Berdasarkan penelitian yang dilakukan, maka dapat diambil beberapa kesimpulan sebagai berikut:

1. Harga buah pisang, harga buah jeruk, harga buah mangga, harga buah salak, harga buah rambutan, pendapatan total, jumlah anggota keluarga, dan tujuan pembelian berpengaruh signifikan terhadap permintaan buah pisang di Kota Denpasar secara simultan.

2. Secara parsial harga buah salak, harga buah rambutan, pendapatan total, jumlah anggota keluarga, tujuan pembelian memberikan kontribusi signifikan terhadap permintaan buah pisang di Kota Denpasar. Sedangkan harga buah pisang, harga buah jeruk, harga buah mangga tidak memberikan kontribusi signifikan terhadap permintaan buah pisang di Kota Denpasar

3. Elastisitas permintaan buah pisang oleh rumah tangga di Kota Denpasar terhadap harga buah pisang bersifat inelastis. Hasil analisis nilai elastisitas pendapatan menunjukkan bahwa buah pisang merupakan barang normal. Buah jeruk dan buah mangga adalah komoditas komplementer. Buah salak dan rambutan adalah komoditas substitusi sebagian yang mengurangi sebagian permintaan pisang.

\section{Saran}

berikut:

Adapun saran-saran yang dapat diajukan di dalam penelitian ini adalah sebagai

1. Permintaan pisang bersifat inelastis terhadap harga, sehingga pedagang masih dapat meningkatkan harga pisang. Disarankan agar petani pisang memelihara pisang dengan lebih baik untuk meningkatkan pendapatan

2. Permintaan pisang bersifat inelastis terhadap harga, maka pemerintah sebaiknya melakukan program pengembangan tanaman pisang yang lebih baik lagi dibandingkan dengan yang sudah ada saat ini agar dapat memenuhi permintaan. 
Pemerintah dalam meningkatkan produksi pisang dapat dilakukan dengan melakukan pembinaan pertanian terutama petani pisang dalam kemampuan dan keterampilan teknis maupun sosial ekonomi. Peningkatan kemampuan dan keterampilan teknis maupun sosial ekonomi dapat dilakukan dengan memberikan penyuluhan budidaya pisang dengan baik sehingga produksinya menjadi lebih meningkat. Peningkatan dan pengendalian produksi pisang di Bali dapat menjaga fluktuasi harga, sehingga harga pisang di Bali menjadi lebih stabil.

3. Perlu diadakannya penelitian dengan jangka waktu yang lebih lama dengan menggunakan trend waktu (time series) sebab pendapatan dan harga cukup berfluktuatif dari bulan ke bulan.

\section{DAFTAR PUSTAKA}

Baye, M.R and Prince, J.T. 2016. Ekonomi Manajerial dan Strategi Bisnis. Salemba Empat. Jakarta

Boediono. 2000. Ekonomi Mikro. BPFE UGM. Yogyakarta

BPS. 2015. Bali dalam Angka 2014. Badan Pusat Statistik. Bali

Departemen Pertanian. 2014. Outlook Komoditi Pisang. Pusat Data dan Informasi Pertanian. Jakarta

Firdaus, Muhammad. 2006. Ekonometrika Suatu Pengenalan Alternatif. Bumi Aksara. Jakarta

Ghozali, L. 2002. Analisis Multivarians Dengan Program SPSS. Lembaga Penelitian Universitas Diponogoro. Semarang.

Gita, P. P. Shinta Dewi. 2013. Pengaruh Harga Canang dan Pendapatan Konsumen Terhadap Permintaan Canang di Desa Sanur, Kecamatan Denpasar Selatan. Skripsi tidak dipublikasikan. Fakultas Ekonomi, Universitas Udayana. Denpasar.

Gujarati, Damodar. 2006. Dasar-Dasar Ekonometrika.Jakarta: Erlangga.

Kastro dan Mantra. 1995. Metode Riset, Edisi Revisi. Erlangga. Jakarta

Lipsey RG, PN Courant, DD Purvis, dan PO Steiner. 1995. Ekonomi Mikro. Wasana AJ, Kibrandoko. Penerjemah. Jakarta : Binarupa Aksara. Terjemahan dari Economics 10th Ed. 345 hal.

Mankiw, N. G, 2011. Pengantar Ekonomi Mikro. Salemba Empat. Jakarta

Pappas, James L. and Hirschey, Mark. 1995. Ekonomi Manajerial. Binarupa Aksara. Jakarta Barat. 